\title{
Defining gay-friendly city as a space of resistance for Indonesian gays in Paris and Jakarta
}

\author{
Wisnu Adihartono ${ }^{1^{*}}$ \\ ${ }^{1}$ Centre Norbert Elias (UMR 8562), Ecole des Hautes Etudes en Sciences Sociales (EHESS), France \\ * Corresponding author \\ E-mail address: wisnuadi.reksodirdjo@gmail.com \\ DOI: https://doi.org/10.21107/sml.v4i2.11103
}

\begin{tabular}{|c|c|}
\hline Article Info & Abstract \\
\hline $\begin{array}{l}\text { Keywords: } \\
\text { gay-friendly city } \\
\text { feeling at home } \\
\text { space of resistance } \\
\text { city of desire } \\
\text { Indonesian gays in } \\
\text { Paris }\end{array}$ & $\begin{array}{l}\text { Migration is associated with the search for a more permissive environment. } \\
\text { By linking Paris as a place of attachment, the author sees that Paris in this } \\
\text { case can be indicated as the "home" for Indonesian gays. The feeling of "full } \\
\text { gay" is a feeling that they never get when they stay in Indonesia. That is } \\
\text { why many Indonesian gays decide to move out of Indonesia in any way } \\
\text { regardless of the difficulties they face in the destination country. This paper } \\
\text { answer two questions: what do we understand by "Gay-friendly city"? And } \\
\text { if we talk about Jakarta, "can Jakarta be categorized as a gay-friendly city"? } \\
\text { The author interviewed eight Indonesian gays directly in Paris with the } \\
\text { naturalistic paradigm and analyzed with the qualitative research, and what } \\
\text { will be found in this paper is the narrative of the eight informants. It can be } \\
\text { said that the Indonesian gays who have migrated to Paris do not feel that } \\
\text { their lives have been wasted. They do diaspora by going to gay bars and } \\
\text { participating in gay pride parades. What they feel is a feeling of freedom to } \\
\text { be able to channel their gender and sexual expression, and they found that } \\
\text { Paris as a gay-friendly city is a kind of space of resistance. }\end{array}$ \\
\hline
\end{tabular}

Citation suggestion:

Adihartono, W. (2021). Defining gay-friendly city as a space of resistance for Indonesian gays in Paris and Jakarta. Simulacra, 4(2), 145-156. https://doi.org/10.21107/sml.v4i2.11103

Received 8 July 2021; Received in revised form 8 September 2021; Accepted 1 October 2021; Published online 25 November 2021. 


\section{Introduction}

When discussing the city as a place, it is often compared to a machine or a living organism. Although outdated, this metaphor expresses the idea that the city is an organized system with an overall structure and subdivided into parts assigned to specific functions such as housing, work, and leisure. These fundamental elements of urban life result from the interactions between the different actors (Fijalkow, 2002). When we talk about the definition of the city, we find a lot of interpretations. Aristotle reminded that the city was a place where people came to live and they stayed to live better (Kotkin, Year not listed). Kotkin therefore made a reflection that in the city, there is a need to have a living well. Living well should not be about where we live but how we live and for whom (Kotkin, Year not listed). The individual of the city seeks a habitat where it will be permanently connected with the whole world. This kind of city therefore, according to Peter Langer (1991) is in the category of the city as a bazaar. The city as a bazaar imagines the city as a place of the astonishing richness of activity and diversity. It is a market, a fair, and a place of almost infinite exploration and a center of exchange. The richness of the city exhibits each individual to foster the development of unique combinations of social affiliations and lifestyles. The author interested in quoting the sentences of Jean-Noël Kapferer (2011) in his chapter Paris as a brand, now interestingly after having learned in 2008 that Paris had lost against London for the hosting of the 2012 Olympic Games, Bertrand Delanoë, Paris Mayor, emitted a diagnosis that Paris has an image that was not as sexy as London. Paris and London in Kapferer's (2011) sentences can be identified as trademarks and can be designed as brands. In the study of marketing, Kotler (1991) declared that a brand can be defined as a name, term, sign, symbol, or design, or combination of them which is intended to identify the goods and services of one seller or group sellers and to differentiate them from those of competitors. From this definition, we find that a brand has an identity that is intended to be a power. In short, according to Riza, Doratli and Fasli (2012) there are three attributes that define city branding: image, uniqueness, and the authenticity thus Paris can be defined as a product of a country (Kapferer, 2011).

As a product of a country for gay people, Paris can be also defined as a gayfriendly city. Gay-friendly city is the places, policies, people, or institutions that are open and welcoming to gay people to create an environment that is supportive of gay people and their relationships, respectful of all people, treat all people equally, and are non-judgmental. As a gay-friendly city, Paris offers gay-friendly places, not only to gays but also to lesbians and transgender people. We can find an area devoted to gay and lesbian groups called Le Marais. This place is often found with gay and lesbian symbols such as rainbow flags, bookstores that specialize in selling books about gay and lesbian romantic relationships, restaurants and coffee shops devoted to gays and lesbians. Of course, this becomes very interesting for the author because such places cannot be found in some Asian countries in particular in Southeast Asian countries. Unfortunately, there has been no further research on whether Indonesia with the city of Jakarta as the capital city can be categorized as a gayfriendly city but Nomadicboys.com stated that there are ten gay-friendly countries in Asia, namely Taiwan, Thailand, Cambodia, Japan, The Philippines, Hong Kong, South Korea, Vietnam, India and Nepal (Arestis, 2021) which can be categorized as a country capable of accommodating the gay rights. Indonesia is not included in the 
list of ten gay-friendly countries because according to the report of International Gay and Lesbian Human Rights Commission (2007), Indonesian LGBT people are often targeted for human rights abuses due to their sexual orientation, gender identity and gender expression. The emergence of a strong heterosexuality norm in Indonesia (Adihartono, 2015) adds to the inequality between men, women and minorities as underlined by Rubin (2011) as:

"Sexuality that is "good", "normal", and "natural" should ideally be heterosexual, marital, monogamous, reproductive, and noncommercial. It should be coupled, relational, within the same generation, and occur at home. It should not involve pornography, fetish object, sex toys of any sort, or roles other that male and female. Any sex that violates these rules is "bad", "abnormal", or "unnatural". Bad sex may be homosexual, unmarried, promiscuous, nonprocreative, or commercial. It may be masturbatory or take place at orgies, may be casual, may cross generational lines, and may take place in "public", or at least in the bushes or the baths. It may involve the use of pornography, fetish objects, sex toys, or unusual roles."

This article tries to answer the doubts about whether Jakarta can be said to be a gay-friendly city by looking at Paris as a comparison effort by defining what we understand about gay-friendly city.

\section{Method}

From the chatting with some Indonesian gay friends in Paris, the author used the naturalistic paradigm but it is not naturalism that has been constructed by natural science in which it needs to be empirically confirmed by observations and experiments (Geuss, 1981). Alan Bryman (1988) clarified that naturalism is one of the intellectual undercurrents to qualitative research in that it proposes that the study of social phenomena should involve the researcher getting close to his or her subjects and not imposing the technical paraphernalia of quantitative on them. In a nutshell, qualitative research focuses on acquiring detailed and intimate information about a small group of people, to learn how and why actors behave rather than focusing on what people do or think on a large scale (Ambert, Adler \& Adler, 1995). Interviews are a ubiquitous way of collecting data in the social sciences.

In this research, the author used the semi-structured interview to approach the informants. This type of interview uses a guide with questions and topics to be asked (Harrell \& Bradley, 2009). Within each topic, the author is free to lead the conversation by asking questions and making some clarifications if the answers are not clear (Corbetta, 2003). In this form, the informants have a lot of freedom to answer questions. For this research, the author interviewed eight Indonesian gays who live in Paris and one who live in Jakarta. The last informant has not been able to go to Paris because he has been exposed to COVID-19. At the time of this research, the informants were aged between 35 and 45 years old and they already had a permanent job. They live with their partners and they have lived in Paris for at most five years.

On the other hand, the author also used the literature research method. This method can be explained as the technique used to classify study, interpret, and identify limitation of physical sources. May (2001) added that this method tells us about additional information at a time when we were not yet born, or were not present. A document is material that provides information about a social phenomenon. 


\section{Results and Discussion}

\section{Gay-friendly city in France context}

If we discuss about gay-friendly city, obviously we discuss about space of resistance. On this, Valentine (2002) explained that space of resistance has a function to reproduce social identity and vice versa, a social identity also has a function to produce something in order to create symbols. But how the space of resistance can be produced? This space must have a very close relationship with the gentrification process which according to Hamnett (2003) gentrification can be translated as the social and spatial manifestation of the transition from an industrial urban to a post-industrial system based on the services of finance, commerce, income, and lifestyles. A city that can be called gay-friendly city usually provides a space that offers anonymity and freedom to act. From this it appears that there is a fairly close relationship between public life and intimacy. Gay neighborhoods, as Giraud (2014) put it, have become recurring figures in urban life in Western metropolises for the past thirty years. The more specific example was shown by the event of Pride Parades which became a symbol of gay friendly city.

Sarah Nusser (2002) in her unpublished paper showed that the significance of the Gay Pride space as the major annual opportunity to affirm positive self-images and self-esteem and also to educate the city about whom gays and lesbians really are and promote understanding. On this, Enguix (2009) pointed out that Pride Parades symbolizes the shift from Gemeinschaft to Gesellschaft which can be interpreted as from gay community to gay culture (Herdt and Boxer, 1992). Pride Parades showed the community from stigma to pride (Enguix, 2009). In June 2015, the author attended a gay pride event held in Paris. It can be seen that many gay, lesbian, and transgender people attended the event as shown in Figure 1 below. However, it can also be seen that many heterosexual people support this event by waving rainbow flags or simply cheering to enliven this event. This indicates that gays, lesbians, and transgender people have at least been recognized by those who come from heterosexual groups, although there are still some who do not agree with

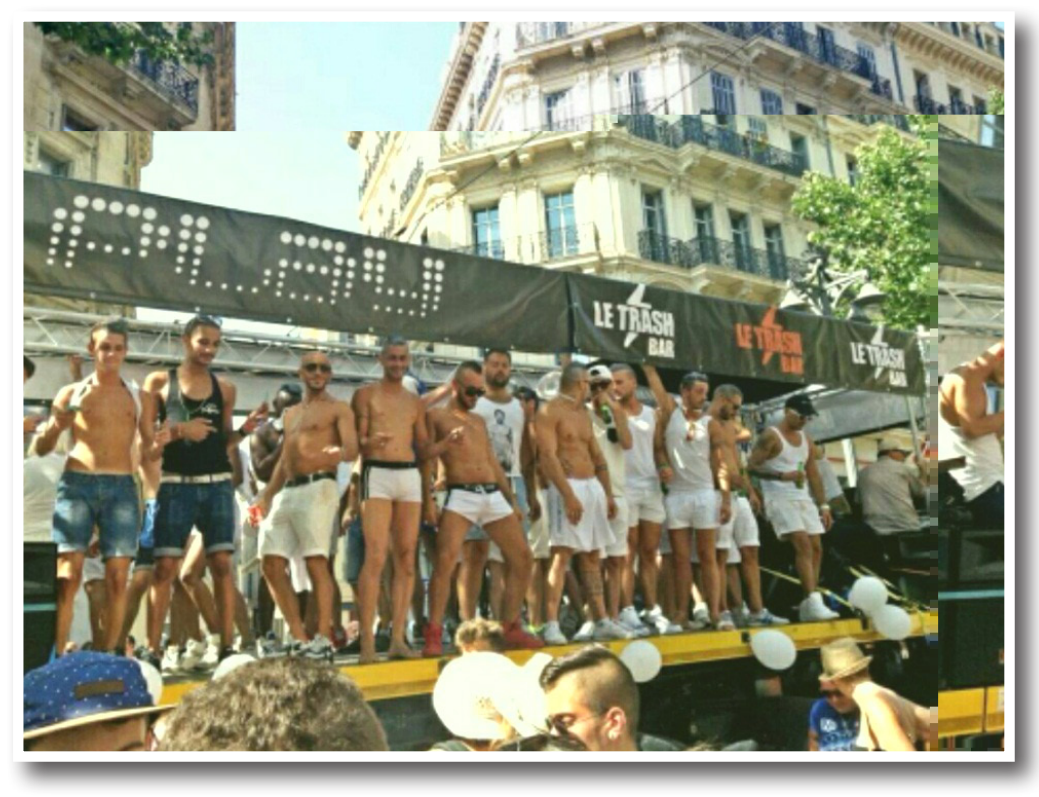

Figure 1: Paris Gay Pride Parade in June 2015.

Source: Private collection of the author 
their existence. However, seeing how lively the event was, it is undeniable that France can be dubbed as a city that is friendly to gays as well as lesbians and transgender people.

Speaking of the concept from Gemeinschaft to Gesellschaft in the case of gayfriendly city, it is very interesting to quote the sentences of Bell and Valentine (1995) which according to them that the Pride Parades event does not just label the streets as queer but they automatically produce queer streets. The process of "queering streets" (Enguix, 2009) transforms the spaces of a city within the framework of diversity between heterosexuals and homosexuals. In short for gay people that Pride Parades can be indicated as seeking safety in gay spaces, a desire to be amongst like-minded individuals, the need to be oneself, to be accepted and to escape from heterosexism (Pritchard, Morgan, Sedgley, Khan \& Jenkins, 2000).

\section{Paris: A city of desire}

Agnes Rocamora (2009) once said that Paris is both a material and a discursive reality, a city of buildings, streets and people, but whose physical tangibility has been the object of a multitude of words and images. Its creation is a product of these two realities. Through them it has arisen as a central site of social distinction, a space, both physical and imagined, attributed a superior value in the socio-cultural hierarchy of French and foreign cities, and a high degree of resonance in the collective landscape. Both a symbol and an inhabited geographical space, Paris has been placed at the center of the French nation (Rocamero, 2009). Paris, it is a city that everyone has dreamed of. Almost everyone wants to spend a vacation in Paris which is very well known with the Eiffel Tower, the Louvre museum, Notre Dame, the cafes which are located in almost every corner, the
Seine, the bridges, the Place de la Concorde, the Champs-Elysées where you can find the shops and the Arche de Triomphe. Many young people want to learn the French language because it is very romantic as well as sexy.

But in reality, Paris which covers 105.4 $\mathrm{km}^{2}$ is a small city compared to London which has an area of $321 \mathrm{~km}^{2}$, Madrid reaches the figure of $607 \mathrm{~km}^{2}$ and Moscow $879 \mathrm{~km}^{2}$ (Pinçon \& Pinçon-Charlot, 2008). Bastié (1992) recalled that there is a myth when one speaks about Paris: the myth of Paris. The reputation of the French capital is attested in literature, arts, and in everyday life. It has been chosen over the centuries by many personalities as a privileged residence. Paris is also a city of desire and can be identified as the European capital of tourism and one of the most important tourist destinations in the world (Freytag, 2008). But beyond Paris as a dream city for everyone, it has also become a dream city for gay communities. The phenomenon of gay neighborhood is increasingly flourishing. This has been shown that in recent decades, homosexuality has acquired a "right to the city" which Leroy (2005) explained that in Paris one can find more gay and lesbian establishments. Regarding this idea, Eribon (1999) observed that Paris, London, Berlin, Amsterdam, New York, and San Francisco have been symbols of a freedom. Leroy (2005) observed that today the gay district in Paris can be seen in the Marais although this area was also inhabited by heterosexuals. In this case, the gay space of the Marais district can be signaled as an open space which has been indicated by the streets, parks, and recreation areas (Tonnelat, 2010). A gay space offers the possibility to connect with other homosexuals and to validate their own identity (Hughes, 2006). The author met Jono (not his real name), 42 in a fast-food restaurant in Barbès. He said: 
"In my opinion, Paris is comfortable. Life is dynamic. Gay life is also very lively. You know Paris is one of the gay cities in Europe? That's why you can find freedom. Do you see the Marais? It's a lovely neighborhood for gays." (Direct interview in Paris)

\section{Feeling at home in Paris}

In homophobic societies, it is clear that many gays and lesbians leave their hometowns to escape discrimination. So, their hometown can no longer be seen as their "home", they choose to migrate to cities or abroad where they can feel a sense of feeling at home. In the eyes of Duyvendak (2011), home is the place that it feels almost like a natural place. They feel safe, secure, and comfortable. Duyvendak's explanation provides the concept that feeling at home is how people emotionally develop an interaction with their environment. This indicates that when people feel marginalized or threatened based on their sexual preferences; they begin to see other places where they can feel the freedom. In this case, the feeling at home is also realized by them during a visit to gay bars in Paris. Gay bars according to Holt and Griffin (2003) are simply places to express an identity. Gay bars are seen as places of acceptance and are used as an escape from the heteronormativity.

Apart from visiting gay bars, the feeling at home can be indicated by their participation in a gay pride. It is well known that each year (generally in June, July or August) several European countries are animated by gay pride. Gay pride is organized to celebrate freedom of sexual identity and to protest against all those who practice homophobia. Johnston (2005) described this event as queer's sites that performs the drag queens, leather bears, buff boys, marching girls, gay parents with their kids, and many more. In order to find out their participation in gay pride, the author asked two questions to Andi (not his real name), 39 who lives in Paris. The questions are: Did you participate in the occasion of gay pride in Paris? And how do you interpret the gay pride? Andi said:

"Yes, I attended the event, not only attended but I also participated in the parade wearing Indonesian traditional clothes that I had modified. There were quite a lot of Indonesian gays who participated in the event but not only gays; there were also Indonesian lesbians and Indonesian transgender. The event was very crowded because we were all parading freedom. Not only parades, but there are also other academic events such as conferences. So don't think that we are doing this just for fun. The point is we are encouraging the existence of LGBTIQ world."

"The gay pride is like a tradition for homosexuals exposing their identities to others. Homosexuality is not a disease at all. So, we must support it."

Visiting the gay bars and participating in the gay pride have become very valuable experiences when they feel feeling at home in Paris. Apart from these two experiences, the author was also curious to know their opinion on the policy of the PaCS or Pacte Civil de Solidarite which was offered by the France Government. After 10 years of debate, the PaCS were promulgated on November 15,1999 . The PaCS is a contract concluded by two adult individuals of the different sex or of the same sex, to organize their life together (Romero, 2011). The PaCS is therefore clearly aimed at people who do not want to get married and the most important is that the PaCS is totally prohibited for the incest relationship (Mécary \& LeroyForgeot, 2000). Since 2001, the number of PaCS increased steadily until 2004. The year 2005 was marked by the record number of 60,473 signatures or more than 120,000 civil partnerships (Jaurand \& Leroy, 2009). As the 
capital of France, Paris has the records for the $\mathrm{PaCS}$. The number of PaCS registrations in the city of Paris weighs over 37\% (Jaurand \& Leroy, 2009). Regarding the image of PaCS, the author asked two questions in order to get their opinions on PaCS: How do you assess the PaCS in the context of France? And, if one day the Indonesian government applied this policy, how do you think? With the direct interview in Paris, Joko (not his real name), 35 said:

"The PaCS well it is a good policy for all couples, either same-sex couples or heterosexual couples. With PaCS, we gain the benefits. I am not French; I am just Indonesian who has a French couple. At least with the PaCS, our rights are equal like heterosexual. I am happy at least."

"Of course, I am agreeing. We cannot create children, we cannot procreate, how do we have children? Of course, we are adopting a baby. If my partner pass away... no... but I imagine... and he has a lot of treasures, then he is going to write a will that I have the right to all earn. If there is no such thing as a policy, how do we adopt a baby? How do we gain the treasures? That is why I am agreeing for the PaCS in Indonesia."

\section{Before and during the COVID-19 pandemic: Jakarta as a gay-friendly city}

Jakarta is the capital city of Indonesia and one of the largest cities. It is located in the northwest of the island of Java near the coast of the Java Sea. As a metropolitan region, Jakarta covers an area of approximately $6.175 \mathrm{~km}^{2}$. Officially referred to as the Special Territory, Jakarta has an administrative body and is headed by a governor. In 2000, Jakarta had a total population of over 21.6 million, consisting of around $80 \%$ urban and 20\% rural population. The national census shows that in 2010 Jakarta was home to 26.6 million inhabitants. Christopher Silver (2008) described that Jakarta is the most populous city in Southeast Asia, the largest city in nation and a region where cities account for less than half the total population. At the societal level, Anggrahita (2012) said that Jakarta society suffers from socio-spatial inequalities. These inequalities are rooted in the legacy of the colonial era. As far as homosexuals are concerned, the authority of the Dutch East Indies distinguished among men. Likewise, during the authoritarian regime, Suharto imposed his agenda to a higher degree. After the political events of 1998, when the authoritarian regime in Soeharto was subjugated by the power of the people and the students, on the contrary, some gay bars, gay nightclubs, and gay saunas emerge in Jakarta. The emergence of gay bars, gay saunas, and gay nightclubs gives the "sign" that Jakarta is also labeled as a gay-friendly city.

One of the lively gay bars located in Bellagio Boutique Mall, Mega Kuningan in South Jakarta is the Apollo. This bar has a stadium or a dance floor with a full sound and lighting system. Some of the most talented DJs liven up this bar with music from the top 40 , tribal, progressive, house music, as well as there are some of go-go dancers which are manly and muscular. Most of the gays who come to the Apollo are upper middle class, although we can also see gays who come from the middle class and people who are not gay. When the author was there, there were performances of people who were topless or without clothes. They danced very sexy while teasing the visitors who came to watch their show. Sometimes visitors gave some money under the folds of their underwear. In addition to the emergence of the Apollo, the presence of Atlantis Gym and Sauna in Kelapa Gading, North Jakarta is also one of the advancements of gay life in Jakarta. This men-only sauna which has a slogan "Do Come In and Have a Good Fuck", offers modern interiors with its complete equipment: a gym of $60 \mathrm{~m}^{2}$, a sauna 
of $150 \mathrm{~m}^{2}$, steam room, whirlpool, dark room where people can have a sexual intercourse and 16 private cabins. Similar to Atlantis Gym and Sauna, the 9M Massage and Sauna that we can found in Talang Betutu street (Jalan Talang Betutu) Central Jakarta is also attracts a lot of gays. On this sauna, the site www.travelgayasia.com noted that $9 \mathrm{M}$ is packed with professional workers on Friday evenings and equally busy with a more diverse local and international crowd on the weekends. The 9M sauna is a great place for fun seekers and those who wish to escape from the hustle and bustle of the city.

But in this case, there is a big difference if we compare these two cities (Paris and Jakarta) in the context of the gay-friendly city. The difference is very visible. In Paris, we can see that the rainbow flags can be seen at the gay mainly areas but in Jakarta, we cannot see the flags. Unexpectedly on this point, the author received some fairly positive responses from three gay informants. With a question: What do you think about gay life in Jakarta? They replied:

"Ok, today there are a lot of cafes in Jakarta. If you go to Sarinah, you can find the Oh La La cafe. There you can find a lot of gays waiting for someone." (Yano lives in Paris (not his real name), 38, Direct interview in Paris)

“Now it's good. I think a lot of progress. Do you know the Oh La La cafe in the Sarinah? That is a cafe that is very well known to gay communities. If we have a coffee there, we can meet this community. For the past three years there has been a gay bar called Heaven in Dharmawangsa district. But it has closed now, I don't know why. I loved going there to see the Drag Queens. The men...oh they were muscular and they were handsome. It's in Jakarta. We don't know what's going on in Surabaya or Yogyakarta? I believe that the developments of gays are also increased."
(Anto lives in Paris (not his real name), 35, Direct interview in Paris)

"...A lot of progress. I have often heard the good news about Indonesian gay life in Jakarta, especially about the openings of cafes that cater for the needs of gays." (Hendra lives in Paris (not his real name), 36, Direct interview in Paris)

Unfortunately, all the bars and gay saunas that the author mentioned above are currently closed due to the COVID-19 pandemic. This is due to the lockdown imposed by the Indonesian government so that many gay bars in Jakarta are out of business because of the lack of visitors. About this problem, the author casually asked about the pandemic and space of resistance to one Indonesian gay who live in Jakarta. The author had a WhatsApp call with Diego (not his real name), 45 years old. Previously he was a bartender at a coffee shop in Jakarta. Currently he has been living in Paris since he was 35 years old and he already has a partner and a permanent job in Paris. He said:

"This pandemic is driving me crazy. How can it not make me crazy if all activities must be limited? I came back from Paris from July this year, I don't think I was contaminated with COVID-19 but a few weeks ago when I did a PCR test to return to Paris, I caught COVID-19 and I had to self-isolate. Speaking of Paris, Paris can be said to be a gay-friendly city. I love living in Paris and I also like the language. Paris is like a city filled with love. All kinds of people exist in Paris. If you want to say Paris is a space of resistance for gay people, I totally agree. I met my partner in Paris... [ ]. Before the pandemic, there were already many bars and saunas devoted to gay groups in Jakarta. For me, Jakarta is already a gay-friendly city. In 2018 I returned to Jakarta for vacation and I still had time to go 


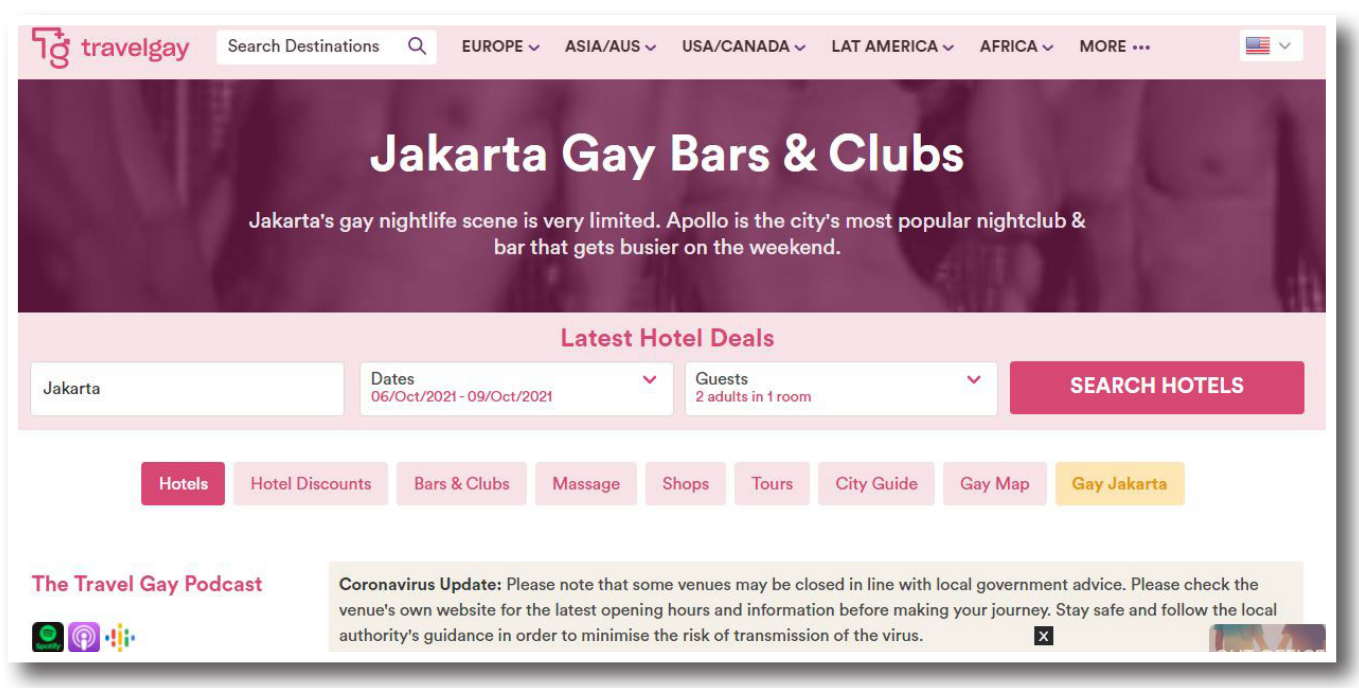

Figure 2: Information about the closing of gay bars in Jakarta due to COVID-19

Source: https://www.travelgay.com/jakarta-gay-bars-and-dance-clubs/

to gay bars and saunas, it was very exciting. But now everything is closed just because of COVID-19. Too bad."

Figure 2 above shows that some gay bars have been closed by their owners. On the internet link that the author found, it was stated that these places had been closed due to COVID-19 due to the lockdown policy carried out by the Indonesian government. Therefore, to carry out their sexual desires such as petting, oral sex and anal sex, they are starting to turn to social media such as Twitter. This is of course a bit strange because they use social media to carry out their sexual desires but because of the lockdown policy, they inevitably have to use their imaginations when they are doing their desires.

Some time ago when the author was writing this paper, the author was chatting with two Indonesian gays who were in Paris about the pandemic and gay lifestyle. They said:

"In Paris, the state of the pandemic is the same as in a big city. Some of them wear masks but some don't. I like being annoyed with those who don't wear masks especially migrants from North Africa. But by the way, I heard that France has started wanting to change its policy of not wearing masks, we'll see. Regarding gay life, don't tell anyone, I have a partner here and when my partner is going to the office, I used to always look for other men. We make love. But now I am a bit worried so I just use Twitter to watch gay porn videos." (Michael lives in Paris (not his real name), 35, Online interview with WhatsApp)

"I already have a partner in Paris but my partner is very liberal. That means that we still have other partners outside. My partner is a busy person so when he is out of town, I usually call my other partners to accompany me. My partner knows about it but it's not a problem. But since the pandemic, I am afraid to have sex with my other partners. Luckily my partner in France has quite a lot of gay porn VCDs so I just watch it when my partner is away. I don't know if my partner has sex with the people he meets." (Hananto lives in Paris (not his real name), 40, Online interview with WhatsApp) 


\section{Conclusion}

For Indonesian gays, migration is associated with the search for a more permissive environment. The liberal environment in large cities has been particularly vital for them to build and explore their homosexual identities. By linking Paris as a space of resistance, the author looked that Paris in this case can be indicated as their home which has an emotional attachment to oneself. The feeling of becoming a "full gay" is a feeling that they never get when they stay in Indonesia. It can be realized that looking at the situation in Indonesia, discussing the issue of homosexuality is still very taboo. That is why many Indonesian gays decided to move out of Indonesia in any way regardless of the difficulties they face in the destination country. They are trying to find a good quality of life and freedom. The social pressures that have been indicated by the stigma lead to the idea of immediately escaping abroad in order to find their identity by building a new life.

All informants of this study told their activities during their stay in Paris. By the time they arrived in Paris most of them feel comfortable although they have to go through various administrative processes and the long process of learning French. They feel that they have their own home even though they actually very far from where they were born and raised have to part with their nuclear and extended families and must work very hard to get the decent life in Paris. But apart from that, they feel that Paris has a space of resistance for gay groups. They perform various diaspora such as going to gay bars, participating in gay pride parades and also discussed the PaCS which were approved by the French Government in 1999. They feel that Paris is a city that has the power to channel their gender expression. As a gay-friendly city, Paris is home to those who have gay sexual preferences as well as lesbians and transgender people.

\section{Acknowledgment}

I would like to thank to all my gatekeepers and informants in Paris and Jakarta, Hafida Meutia and Citra Megasari who has supported this research.

\section{Declaration of Ownership}

This article is my original work.

\section{Conflict of Interest}

All informants have agreed that their opinions will be included in this paper under a pseudonym. Only age may be listed according to the original.

\section{Ethical Clearance}

This study was approved by the institution.

\section{References}

Adihartono, W. (2015). Homosexuality in Indonesia: Banality, prohibition and migration (the case of Indonesian gays). International Journal of Indonesian Studies, 1(2), 18-32.

Ambert, A. M., Adler, P. A., Adler, P., \& Detzner, D. F. (1995). Understanding and evaluating qualitative research. Journal of Marriage and Family, 57(4), 879-893. https://doi.org/10.2307/353409

Anggrahita, H. (2012). L'utilisation de l'eau domestique: Perception et attitudes à Jakarta (Indonésie). EchoGéo, 22, 1-32. https://doi.org/10.4000/echogeo.13299

Arestis, S. (2021). 10 most gay friendly city in Asia. Nomadicboys. https://nomadicboys. com/most-gay-friendly-countries-in-asia 
Bastié, J. (1992). Paris, ville mondiale. In Wackemann, G. (Ed.), La France dans le Monde. Nathan.

Blackwood, E. (2007). Regulation of sexuality in Indonesia discourse: Normative gender, criminal law and shifting strategies of control. Culture, Health and Society, 9(3), 293-307. htpps://www.jstor. org/stable/20460931

Bryman, A. (1988). Quantity and quality in social research. Unwin Hyman.

Corbetta, P. (2003). Social research: Theory, methods and techniques. Thousand Oaks.

Duyvendak, J. W. (2011). The politics of home: Belonging and nostalgia in Western Europe and the United States. Palgrave Macmillan.

Enguix, B. (2009). Identities, sexualities and commemorations: Pride parades, public space and sexual dissidence. Anthropological Notebooks, 15(2), 1533. http://www.drustvoantropologov. si/AN/PDF/2009_2/Anthropological_ Notebooks_XV_2_Enguix.pdf

Eribon, D. (1999). Réflexion sur la question gay. Fayard.

Fijalkow, Y. (2002). Sociologie de la ville. La Decouverte.

Freytag, T. (2008). Making a difference: Tourist practices of repeat visitors in the city of Paris. Social Geography Discussions, 4, 1-25. htpps://www.socgeogr-discuss.net/4/1/2008/sgd-4-1-2008. pdf

Geuss, R. (1981). The idea of critical theory: Habermas and the Frankfurt school. Cambridge University Press.

Giraud, C. (2014). Quartiers gays. Presses Universitaires de France.

Guaracino, J. (2007). Gay and lesbian tourism: The essential guide for marketing. Elsevier Ltd.

Hamnett, C. (2003). Gentrification and the middle-class remaking of inner London,
1961-2001. Urban Studies, 40(12). htpps:// doi.org/10.1080/0042098032000136138

Harrell, M. C., \& Bradley, M. A. (2009). Training manual: Data collection methods. Semi-Structured Interviews and Focus Groups. National Defense Research Institute.

Herdt, G., \& Boxer. A. (1992). Introduction: Culture, history, and life course of gay men. In Herdt, G. (Ed.), Gay culture in America: Essays from the field. Beacon Press.

Hughes, H. L. (2006). Pink tourism: Holidays of gay men and lesbians. CABI.

International Gay and Lesbian Human Rights Commission. (2007). Human rights abuses againts sexual minorities in Indonesia. Report, November.

Jaurand, E., \& Leroy, S. (2009). Espaces de pacs: Géographie d'une innovation sociale. Annales de Géographie, 667, 179203. htpps://doi.org/10.3917/ag.667.0179

Kapferer, J. N. (2011). Paris as a brand. In Keith Dinnie, City branding: Theory and cases. Palgrave Macmillan

Kotkin, J. (Year not listed). What is a city for? In Working Paper Series, 1, Lee Kuan Yew Centre for Innovative Cities. University of Technology and Design.

Kotler, P. (1991). Marketing management: Analysis, planning, and control. PrenticeHall, Inc.

Langer, P. (1991). Sociology-four images of organized diversity: Bazaar, jungle, organism, and machine. In Rodwin, L., \& Hollister, R. M. (Eds.), Cities of the mind images and themes of the city in the social sciences. Springer.

Leroy, S. (2005). Le Paris gay. Elément pour une géographie de l'homosexualité. Annales de Géographie, 646, 579-601. htpps://doi.org/10.3917/ag.646.0579

May, T. (2001). Social research: Issues, methods and process. Open University Press. 
Mécary, C., \& Leroy-Forgeot, F. (2000). Le PACS. Presses Universitaires de France.

Packer, M. (2011). The science of qualitative research. Cambridge University Press.

Pinçon, M., \& Pinçon-Charlot, M. (2008). Sociologie de Paris. Edition La Découverte.

Pritchard, A., Morgan, N. J., Sedgley, D., Khan, E., \& Jenkins, A. (2000). Sexuality and holiday choices: Conversations with gay and lesbian tourists. Leisure Studies, 19, 267-282. htpps://doi. org/10.1080/02614360050118832

Riza, M., Dorotli N., \& Fasli, M. (2012). City branding and identity. Procedia Social and Behavioral Science. htpps://doi. org/10.1016/J.SBSPRO.2012.02.091

Rocamora, A. (2009). Fashioning the city: Paris, fashion and the media. Bloomsbury Publishing.

Romero, J. L. (2011). Homopoliticus, comme ils dissent homosexualité et politique en France: d'un tabou à un sujet électoraliste, de 1960 à nous jours. Florent Massot.

Rubin, G. (2011). Deviations: A Gayle Rubin reader. Duke University Press.

Sarah, N. (2002). What would a non-heterosexist city look like? A theory on queer spaces and the role of planners in creating the inclusive city. Department of Urban Studies and Planning, Massachusetts Institute of Technology.

Silver, C. (2008). Planning the megacity: Jakarta in the twentieth century. Routledge.

Stéphane, T. (2010). The sociology of urban public spaces. In Hongyang, W., Michel, S., \& Guofang, Z. (Eds.), Territorial evolution and planning solution: Experiences from China and France. Atlantis Press.

Valentine, G. (2002). Queer bodies and the production of space. In Richardson, D., \& Seidman, S (Eds.), Handbook of lesbian and gay studies. Sage. 